\title{
Association of $X R C C 1$ gene polymorphisms with the susceptibility and chromosomal aberration of testicular germ cell tumors
}

\author{
NORIHIKO TSUCHIYA ${ }^{1}$, MUTSUKI MISHINA ${ }^{2}$, SHINTARO NARITA ${ }^{1}$, TERUAKI KUMAZAWA ${ }^{1}$, \\ TAKAMITSU INOUE ${ }^{1}$, YOHEI HORIKAWA ${ }^{1}$, HIDEAKI KAKINUMA ${ }^{1}$, TAKESHI YUASA ${ }^{1}$, \\ SHINOBU MATSUURA ${ }^{1}$, SHIGERU SATOH ${ }^{1}$, OSAMU OGAWA ${ }^{3}$ and TOMONORI HABUCHI ${ }^{1}$ \\ ${ }^{1}$ Department of Urology, Akita University School of Medicine; ${ }^{2}$ Department of Urology, \\ National Hospital Organization Mito Medical Center; ${ }^{3}$ Graduate School of Medicine, Kyoto University, Japan
}

Received November 22, 2005; Accepted January 9, 2006

\begin{abstract}
It is known that many genomic and genetic alterations caused by aging or environmental factors are responsible for cancer development and progression. XRCC1 is involved in the repair of DNA single-strand breaks formed by exposure to ionizing radiation and alkylating agents. The objective of this study was to investigate the association of genomic alterations and the susceptibility of testicular germ cell tumors with XRCC1 polymorphisms. Two polymorphisms of XRCC1, Arg194Trp and Arg399Gln, were genotyped in 83 patients with testicular germ cell tumors (TGCT) and 87 male controls. Allelic imbalances (AI) were evaluated using 4 microsatellite markers in a subgroup of 50 patients. Patients with at least one Gln allele of the Arg399Gln polymorphism had an increased risk of TGCT than those with the Arg/Arg genotype $(\mathrm{aOR}=1.775,95 \% \mathrm{CI}=1.045-3.016, \mathrm{P}=0.034)$. Furthermore, the increased risk associated with the Gln allele against the Arg homozygote was more strongly observed in patients with pure seminoma $(\mathrm{aOR}=2.242,95 \% \mathrm{CI}=1.149-4.374, \mathrm{P}=0.018)$ or with metastasis $(\mathrm{aOR}=2.481,95 \% \mathrm{CI}=1.267-4.862, \mathrm{P}=0.008)$. In the Arg194Trp polymorphism, there was no significant difference in the genotype distribution between TGCT patients and the controls. In AI analysis, the frequency of AI was significantly higher in tumors with at least one Gln allele than those with the Arg/Arg genotype in D13S317 $(\mathrm{P}=0.010)$ and in a combination of 4 markers $(0.51 \pm 0.32$ vs $0.32 \pm 28, \mathrm{P}=0.028)$. Our results suggest that the Gln allele of the XRCC1 Arg399Gln polymorphism may genetically modify the development and progression of TGCT through genomic instability.
\end{abstract}

Correspondence to: Dr Tomonori Habuchi, Department of Urology, Akita University School of Medicine, 1-1-1 Hondo, Akita 010-8543, Japan

E-mail: thabuchi@doc.med.akita-u.ac.jp

Key words: testicular germ cell tumor, XRCC1 polymorphism, allelic imbalance

\section{Introduction}

Testicular germ cell tumor (TGCT) is the most common solid malignancy among young males $(1,2)$. The incidence of TGCT has been increasing worldwide, although there is a marked difference in the incidence, with a higher rate in Scandinavian countries, Germany and Switzerland, and a lower rate in Africa and Asia (3). In recent studies, Finnish men who emigrated to Sweden had a risk of TGCT that is reportedly compatible with that of men in Finland despite a $4 x$ lower incidence ratio in the Finnish than the Swedish population $(4,5)$. These findings suggest that the risk of TGCT is possibly determined by environmental exposure early in life. Several risk factors for TGCT, including an undescended testis (cryptorchism), history of TGCT, and infertility, have been reported (6). Although little is known about the etiology of TGCT, in utero exposure to diethylstilbestrol or endogenous estrogens, and early exposure to viruses or chemical substances are hypothesized to be causes of the increased incidence and geographic differences (7-10). Geographic differences in the incidence of TGCT may be modified by genetic factors. This hypothesis is supported by the observation that the relative risk of TGCT is 7- to 10- and 4-fold higher in the brothers and sons of TGCT patients, respectively (11). Recent epidemiological studies have revealed that many genetic polymorphisms are associated with the development and progression of malignant tumors. However, most studies failed to find an association between the risk of TGCT and genetic polymorphisms including androgen receptor, estrogen receptor, detoxification enzyme, and several DNA repair genes (12-15), although only a few studies found an association between polymorphisms and the risk of TGCT (16).

It is known that many genomic and genetic alterations caused by aging or environmental factors are responsible for cancer development and progression. Various chromosomal aberrations $(17,18)$ or gene mutations $(19,20)$ in TGCTs have been reported and these accumulative genetic alterations are considered to be implicated in the tumorigenesis of TGCT. Chromosomal aberrations, which are detected by PCRbased analysis of allelic imbalance (AI), in situ fluorescent hybridization (FISH), or comparative genomic hybridization (CGH), are induced by DNA damage possibly due to single or double-strand breaks (21). In TGCTs, many chromosomal 
Table I. Association of XRCC1 polymorphisms with the susceptibility of testicular germ cell tumors.

\begin{tabular}{|c|c|c|c|c|}
\hline \multirow[b]{2}{*}{ Arg194Trp } & \multicolumn{2}{|c|}{ No. of genotype (\%) } & \multirow[b]{2}{*}{ aOR $(95 \% \mathrm{CI})$} & \multirow[b]{2}{*}{ P-value } \\
\hline & $\operatorname{Arg} / \operatorname{Arg}$ & $\operatorname{Arg} / \operatorname{Trp}+\operatorname{Trp} / \operatorname{Trp}$ & & \\
\hline Normal control $(n=89)$ & $44(49.4)$ & $36+9(50.6)$ & 1.000 (ref.) & \\
\hline \multirow[t]{2}{*}{ TGCT $(\mathrm{n}=85)$} & $43(50.6)$ & $36+6(49.4)$ & $0.902(0.568-1.434)$ & 0.664 \\
\hline & \multicolumn{2}{|c|}{ No. of genotype (\%) } & & \\
\hline Arg399Gln & $\mathrm{Arg} / \mathrm{Arg}$ & $\mathrm{Arg} / \mathrm{Gln}+\mathrm{Gln} / \mathrm{Gln}$ & aOR $(95 \% \mathrm{CI})$ & P-value \\
\hline Normal control $(\mathrm{n}=89)$ & $52(58.4)$ & $35+2(41.6)$ & 1.000 (ref.) & \\
\hline TGCT $(n=85)$ & $37(43.5)$ & $42+6(56.5)$ & $1.831(1.077-3.010)$ & 0.025 \\
\hline
\end{tabular}

alterations, including loss of chromosomes $4,5,11,13 \mathrm{q}, 17 \mathrm{p}$ and $18 \mathrm{q}$, and gain of chromosomes $7,8,12,15 \mathrm{q}$ and $21 \mathrm{q}$, have been described. The rate of chromosomal alteration may be modulated by the capacity of DNA repair proteins, such as the X-ray repair complementing defective in Chinese hamster $1 \mathrm{X}$-ray repair cross complementing protein (XRCC) 1 as a base excision repair protein or XRCC3 as a homologous double-strand break repair protein (21).

The XRCCl gene has three single nucleotide polymorphisms (SNPs), Arg194Trp, Arg280His, and Arg399Gln, in exons 6, 9 and 10, respectively. Although the functional significance of these polymorphisms is not fully understood, several studies have shown the association of XRCC1 function and the Arg399Gln polymorphism. The Arg399Gln polymorphism is located in the BRCA1 carboxyl-terminal (BRCT)I domain which binds to poly(ADP-ribose) polymerase 1 (PARP-1) activated after DNA damage, and the 399Gln allele is reportedly associated with reduced DNA repair function, p53 mutations, and an increased frequency of sister chromatid exchanges (22-24). The Arg194Trp polymorphism is located in the proliferating cell nuclear antigen (PCNA) binding region (4) and is suggested to alter the DNA repair capacity of XRCC1 (25). Several epidemiological studies have demonstrated the association of XRCC1 polymorphisms with the risk of many cancers, including head and neck, lung, and breast cancers (26-28). However, some other studies have contradicted this association of XRCC1 polymorphisms with DNA repair functions $(22,29)$ or with cancer susceptibility (30-32).

In this study, we examined the association of XRCC1 polymorphisms with the risk and clinicopathological features of TGCT and analyzed AIs to assess the association with $X R C C 1$ polymorphisms and chromosomal alterations.

\section{Materials and methods}

Subjects and tissue samples. We studied 89 male controls and 85 patients with pathologically diagnosed primary TGCT treated at Akita University Medical Center or Kyoto University Hospital. The testicular tumors comprised 44 seminomas and 41 non-seminomatous germ cell tumors. The mean ages $( \pm \mathrm{SD})$ of the patients and control were $35.2 \pm 12.0$ (range, 2-64) and
33.3 \pm 13.8 (range, 23-63) years, respectively. Control subjects were recruited among students of Kyoto University or healthy subjects attending a health 'check-up'. No significant difference in the mean age was found between the patients and control $(\mathrm{P}=0.327)$. This study was approved by the Institutional Review Board (the Ethics Committee) of the Akita University School of Medicine, Akita, Japan and the Kyoto University Graduate School of Medicine, Kyoto, Japan. Written informed consent was obtained from all subjects for the use of their DNA from peripheral blood and resected specimens, and clinical information. Pathological diagnosis and clinical stage were determined according to modified WHO and TNM classifications, respectively $(33,34)$. These clinicopathological data are summarized in Table I. Blood samples were collected from each subject and DNA was extracted using a QIAamp Blood Kit (Qiagen, Hilden, Germany). In 50 patients, DNA was extracted from tumors by the standard method with proteinase $\mathrm{K}$ digestion followed by phenol-chloroform extraction.

Genotyping of XRCC1 gene polymorphisms. Polymerase chain reaction restriction fragment length polymorphism (PCR-RFLP) was used to detect the XRCC1 Arg194Trp and Arg399Gln polymorphisms. The primer sets were as follows: XRCC1 Arg194Trp forward, 5'-ATGCTTGGCCAGTTCCG TGTGAAG-3', and reverse, 5'-CACCTGGGGATGTCTTGT TGATCC-3'; XRCC1 Arg399Gln forward, 5'-TCCTCCACC TTGTGCTTTCT-3', and reverse, 5'-AGTAGTCTGCTGGC TCTGGG-3'. PCR was carried out in a $15 \mu 1$ aliquot containing $\sim 25 \mathrm{ng}$ of genomic DNA, $12 \mathrm{pmol}$ of each primer, $2.5 \mu \mathrm{l}$ of $10 \mathrm{X}$ buffer solution, $20 \mathrm{nmol} / \mu 1$ each of dATP, dCTP, dGTP, and dTTP, and $1 \mathrm{U}$ of Taq polymerase (Ampli-Taq Gold DNA polymerase, PE Applied Biosystems, Branchburg, NJ, USA). Initial denaturation at $94^{\circ} \mathrm{C}$ for $10 \mathrm{~min}$ was followed by 35 cycles of denaturation at $94^{\circ} \mathrm{C}$ for $30 \mathrm{sec}$, annealing at $57^{\circ} \mathrm{C}$ for $\operatorname{Arg} 194 \operatorname{Trp}$ and at $61^{\circ} \mathrm{C}$ for $30 \mathrm{sec}$ for $\operatorname{Arg} 399 \mathrm{Gln}$, and extension at $72^{\circ} \mathrm{C}$ for $30 \mathrm{sec}$, with a final extension at $72^{\circ} \mathrm{C}$ for $7 \mathrm{~min}$. The products obtained by overnight digestion with $\mathrm{AluI}$ or $\mathrm{Nci}$ I were electrophoresed on $3.0 \%$ agarose gels, respectively. The PCR products of $100 \mathrm{bp}$ and $517 \mathrm{bp}$, for the Arg194Trp and the Arg399Gln polymorphisms respectively, contain $A l u \mathrm{I}$ and $N c i$ I restriction sites and digestion of the PCR products results in two fragments of 76 and $24 \mathrm{bp}$ and 
Table II. Association of XRCC1 polymorphisms with pathological type and clinical stage.

\begin{tabular}{|c|c|c|c|c|}
\hline \multirow[b]{2}{*}{ Arg194Trp } & \multicolumn{2}{|c|}{ No. of genotype (\%) } & \multirow[b]{2}{*}{ aOR $(95 \% \mathrm{CI})$} & \multirow[b]{2}{*}{ P-value } \\
\hline & Arg/Arg & $\operatorname{Arg} / \operatorname{Trp}+\operatorname{Trp} / \operatorname{Trp}$ & & \\
\hline Normal control $(n=89)$ & $44(49.4)$ & $36+9(50.6)$ & 1.000 (ref.) & \\
\hline Pure seminoma $(n=44)$ & $21(38.6)$ & $20+3(61.4)$ & $0.992(0.554-1.773)$ & 0.977 \\
\hline Mixed GCT $(\mathrm{n}=41)$ & $22(47.4)$ & $16+3(52.6)$ & $0.841(0.470-1.504)$ & 0.560 \\
\hline Stage I $(n=38)$ & $14(36.8)$ & $20+4(63.2)$ & $1.338(0.751-2.385)$ & 0.323 \\
\hline \multirow[t]{2}{*}{ Stage II-III (n=42) } & $26(61.9)$ & $14+2(38.1)$ & $0.635(0.345-1.166)$ & 0.143 \\
\hline & \multicolumn{2}{|c|}{ No. of genotype (\%) } & & \\
\hline Arg399Gln & Arg/Arg & $\mathrm{Arg} / \mathrm{Gln}+\mathrm{Gln} / \mathrm{Gln}$ & aOR $(95 \% \mathrm{CI})$ & P-value \\
\hline Normal control $(n=89)$ & $52(58.4)$ & $35+2(41.6)$ & 1.000 (ref.) & \\
\hline Pure seminoma $(n=44)$ & $17(38.6)$ & $23+4(61.4)$ & $2.242(1.149-4.374)$ & 0.018 \\
\hline Mixed GCT $(n=41)$ & $20(47.4)$ & $19+2(52.6)$ & $1.365(0.696-2.677)$ & 0.365 \\
\hline Stage I $(n=38)$ & $20(52.6)$ & $16+2(47.4)$ & $1.444(0.724-2.878)$ & 0.297 \\
\hline Stage II-III (n=42) & $14(33.3)$ & $25+3(66.7)$ & $2.550(1.303-4.990)$ & 0.006 \\
\hline
\end{tabular}

385 and 132 bp with a Trp and Gln allele, respectively. Several samples were directly sequenced using PCR primers and Dye Terminator Sequencing Kit version 1.0 (PE Applied Biosystems) on an ABI PRISM 310 auto-sequencer to confirm the results of PCR-RFLP for each polymorphism.

Analysis of allelic imbalance (AI). AI was analyzed in 4 microsatellite markers, D11S1392, D13S317, TP53, and D18S538, which reportedly showed frequent AI using paired DNA obtained from tumor and peripheral blood in a subgroup of 50 patients (18). The nucleotide sequences of forward and reverse primers used for PCR were 5'-TTGCATCCATACG GAAAGTC-3' and 5'-ACATCTGAGACTTGTAGTAGAAG GC for D11S1392, 5'-ACAGAAGTCTGGGATGTGGA-3' and 5'-GCCCAAAAA6ACAGACAGAA-3' for D13S317, 5'AGGATACTATTCAGCCCGAGGTG-3' and 5'-ACTGCCA CTCCTTGCCCCATTC-3' for TP53, and 5'-AAGCTGAGT GAGCCAATACC-3' and ATTCTCCAGACAAATAATA CC-3' for D18S538. Each forward primer was labeled with HEX (a fluorescent dye). The PCR reaction was carried out in a final volume of $15 \mu \mathrm{l}$ containing $20 \mathrm{ng}$ of genomic DNA, 5 pmol of each primer, $0.2 \mathrm{mM}$ of each dNTP, $1.0 \mathrm{mM}$ of $\mathrm{MgCl}_{2}$, and 0.5 unit of Ampli-Taq Gold DNA polymerase (Perkin-Elmer, Branchburg, NJ). Initial denaturation at $94^{\circ} \mathrm{C}$ for $10 \mathrm{~min}$ was followed by 26 cycles of denaturation at $94^{\circ} \mathrm{C}$ for $30 \mathrm{sec}$, annealing at $55^{\circ} \mathrm{C}$, and extension at $72^{\circ} \mathrm{C}$ for $30 \mathrm{sec}$, with final extension at $72^{\circ} \mathrm{C}$ for $7 \mathrm{~min}$. One $\mu 1$ of the PCR product and $0.5 \mu \mathrm{l}$ of the size marker [GS-ROX400-HD (Applied Biosystems, Foster, CA)] were diluted to $20 \mu 1$ with HiDi formamide loading buffer and heat-denatured at $95^{\circ} \mathrm{C}$ for 5 min. The mixture was then analyzed using an ABI PRISM 310 automated DNA sequencer (Applied Biosystems) and GeneScan (version 3.1) (Applied Biosystems). AI was determined by measuring the signal imbalance between the opposing alleles and defined as the presence of AI when one signal peak in a PCR product from tumor DNA was less than $70 \%$ of that from the corresponding peripheral blood DNA.

Statistical analysis. All data were analyzed by SSPS version 11.0J software (SSPS Inc., Chicago, IL). Hardy-Weinberg equilibrium analyses were performed to compare the observed genotype frequencies with those expected using the $\chi^{2}$ test. The age-adjusted odds ratio (aOR) and $95 \%$ confidence interval (CI) for the relative risk of prostate cancer in each genotype were determined by multiple logistic regression analysis with the inclusion of an age factor. The relationship between each genotype and the AI status was analyzed by $\chi^{2}$ analysis. A probability of $<0.05$ was required for statistical significance.

\section{Results}

Association of XRCC1 polymorphisms with the risk of testicular germ cell tumors. The genotype distribution and allele frequency of XRCC1 polymorphisms are summarized in Table I. The genotype distribution in each polymorphism was in Hardy-Weinberg disequilibrium. The genotypes using peripheral blood DNA were completely identical with those using DNA obtained from corresponding tumor tissue, thus demonstrating the absence of the somatic alteration of $X R C C 1$. To evaluate the risk of TGCT according to XRCC1 polymorphisms, logistic regression analysis was employed with age adjustment at diagnosis. There was no significant association between the Arg194Trp polymorphism and the risk of TGCT $(\mathrm{aOR}=0.902,95 \% \mathrm{CI}=0.568-1.434, \mathrm{P}=0.664)$. When the subjects were divided into two groups according to the presence of the Gln allele of the Arg399Gln polymorphism, Gln allele carriers had a significantly increased risk of TGCT compared to non-Gln allele carriers $(\mathrm{aOR}=1.831$, $95 \% \mathrm{CI}=1.077-3.010, \mathrm{P}=0.025$ ). 
Table III. Association of XRCC1 polymorphisms with allelic imbalances in four loci.

\begin{tabular}{|c|c|c|c|c|c|c|c|}
\hline \multirow[b]{2}{*}{ Locus } & \multirow[b]{2}{*}{ Allelic imbalance } & \multicolumn{2}{|c|}{ Arg194Trp } & \multirow[b]{2}{*}{ P-value } & \multicolumn{2}{|c|}{ Arg399Gln } & \multirow[b]{2}{*}{ P-value } \\
\hline & & Arg/Arg & Arg/Trp $+\operatorname{Trp} / \operatorname{Trp}$ & & Arg/Arg & $\mathrm{Arg} / \mathrm{Gln}+\mathrm{Gln} / \mathrm{Gln}$ & \\
\hline \multicolumn{8}{|l|}{ Overall } \\
\hline \multirow[t]{2}{*}{ D11S1392 } & - & $12(66.7)$ & $14(58.3)$ & & $11(64.7)$ & $15(60.0)$ & \\
\hline & + & $6(33.3)$ & $10(41.7)$ & 0.750 & $6(35.3)$ & $10(40.0)$ & 1.000 \\
\hline \multirow[t]{2}{*}{ D13S317 } & - & $9(50.0)$ & $8(36.4)$ & & $12(66.7)$ & $5(22.7)$ & \\
\hline & + & $9(50.0)$ & $14(63.6)$ & 0.523 & $6(33.3)$ & $17(77.3)$ & 0.010 \\
\hline \multirow[t]{2}{*}{ TP53 } & - & $15(71.4)$ & $15(60.0)$ & & $16(76.2)$ & $14(56.0)$ & \\
\hline & + & $6(28.6)$ & $10(40.0)$ & 0.538 & $5(23.8)$ & $11(44.0)$ & 0.217 \\
\hline \multirow[t]{2}{*}{ D18S538 } & - & $10(62.5)$ & $10(47.6)$ & & $10(58.8)$ & $10(50.0)$ & \\
\hline & + & $6(37.5)$ & $11(54.1)$ & 0.508 & $7(41.2)$ & $10(50.0)$ & 0.743 \\
\hline \multicolumn{8}{|c|}{ Pure seminoma } \\
\hline \multirow[t]{2}{*}{ D11S1392 } & - & $4(50.0)$ & $9(60.0)$ & & $5(62.5)$ & $8(53.3)$ & \\
\hline & + & $4(50.0)$ & $6(40.0)$ & 0.685 & $3(37.5)$ & $7(46.7)$ & 1.000 \\
\hline \multirow[t]{2}{*}{ D13S317 } & - & $5(55.6)$ & $6(46.2)$ & & $8(80.0)$ & $3(25.0)$ & \\
\hline & + & $4(44.4)$ & $7(53.8)$ & 1.000 & $2(20.0)$ & $9(75.0)$ & 0.030 \\
\hline \multirow[t]{2}{*}{ TP53 } & - & $10(83.3)$ & $11(68.8)$ & & $11(91.7)$ & $10(62.5)$ & \\
\hline & + & $2(16.7)$ & $5(31.3)$ & 0.662 & $1(8.3)$ & $6(37.5)$ & 0.184 \\
\hline \multirow[t]{2}{*}{ D18S538 } & - & $6(66.7)$ & $7(53.8)$ & & $6(75.5)$ & $7(50.0)$ & \\
\hline & + & $3(33.3)$ & $6(46.2)$ & 0.674 & $2(25.5)$ & $7(50.0)$ & 0.380 \\
\hline
\end{tabular}

When TGCT patients were stratified by pathological type and clinical stage, there were no significant differences between the pure seminoma and mixed germ cell tumor, and between early stage (stage I) and advanced stage (stage II-III) TGCT in each polymorphism (data not shown). However, when compared with control subjects, a significantly increased risk associated with the Gln allele of the Arg399Gln polymorphism was observed in patients with pure seminoma (aOR=2.242; 95\% $\mathrm{CI}=1.149-4.374 ; \mathrm{P}=0.018$ ) or advanced stage $(\mathrm{aOR}=2.550 ; 95 \% \mathrm{CI}=1.303-4.990 ; \mathrm{P}=0.006)$, whereas the risk was not significant in those with mixed germ cell tumors $(\mathrm{aOR}=1.365 ; 95 \% \mathrm{CI}=0.696-2.677 ; \mathrm{P}=0.365)$ or early stage $(\mathrm{aOR}=1.444 ; 95 \% \mathrm{CI}=0.724-2.878 ; \mathrm{P}=0.431)$ (Table II). There were no associations between the Arg194Trp polymorphism and either tumor type or clinical stage (data not shown).

Association of XRCC1 polymorphisms with allelic imbalance. The association between XRCC1 polymorphisms and AI is summarized in Table III and a representative AI case of each locus is shown in Fig. 1. The number of informative cases (heterozygotes at tested loci) was $42(84.0 \%), 40(80.0 \%), 46$ $(92.0 \%)$, and $37(74.0 \%)$ and AI was observed in $16(38.1 \%)$, $23(57.5 \%), 16(34.8 \%)$, and $17(45.9 \%)$ cases for D11S1392, D13S317, TP53, and D18S538, respectively. When all analyzed cases were included, the presence of the Gln allele of the Arg399Gln polymorphism had a significant association with the AI of D13S317 $(\mathrm{P}=0.010)$. Although the tumors showing AI had a tendency toward an increased number of Gln allele carriers in other loci, there were no statistical significances. The Arg194Trp polymorphism was not associated with the AI of any loci. The association between the AI of each locus and the polymorphisms in a subgroup of pure seminoma was analyzed. The presence of the Gln allele of the Arg399Gln polymorphism was only significantly associated with the AI of D13S317 ( $\mathrm{P}=0.030)$, although the tumors showing AI only had a tendency toward an increased number of Gln allele carriers in other loci. The Arg194Trp polymorphism was not associated with the AI of any loci in the subgroup of pure seminoma. The mean AI frequency of the four loci analyzed in this study was compared between tumors with Arg/Arg genotype and those with Arg/Gln or Gln/Gln genotype. Tumors with at least one Gln allele had a significantly higher frequency of overall $\mathrm{AI}$ than those with the Arg/Arg genotype $(0.50 \pm 0.33$ vs $0.21 \pm 0.13, \mathrm{P}=0.018)$ when all cases were included (Fig. 2A). In the subgroup of pure seminoma, the frequency of AI in tumors with the Gln allele showed a significantly higher frequency than those with the Arg/Arg genotype $(0.51 \pm 0.32$ vs $0.32 \pm 0.28, \mathrm{P}=0.028)$ (Fig. 2B).

\section{Discussion}

Previous epidemiological studies have demonstrated various risk factors of TGCT. Among these factors, cryptorchism, carcinoma in situ, and in utero exposure to estrogens are 


\section{$\begin{array}{llll}\text { D11S1392 D13S317 } & \text { TP53 } & \text { D18S538 }\end{array}$}

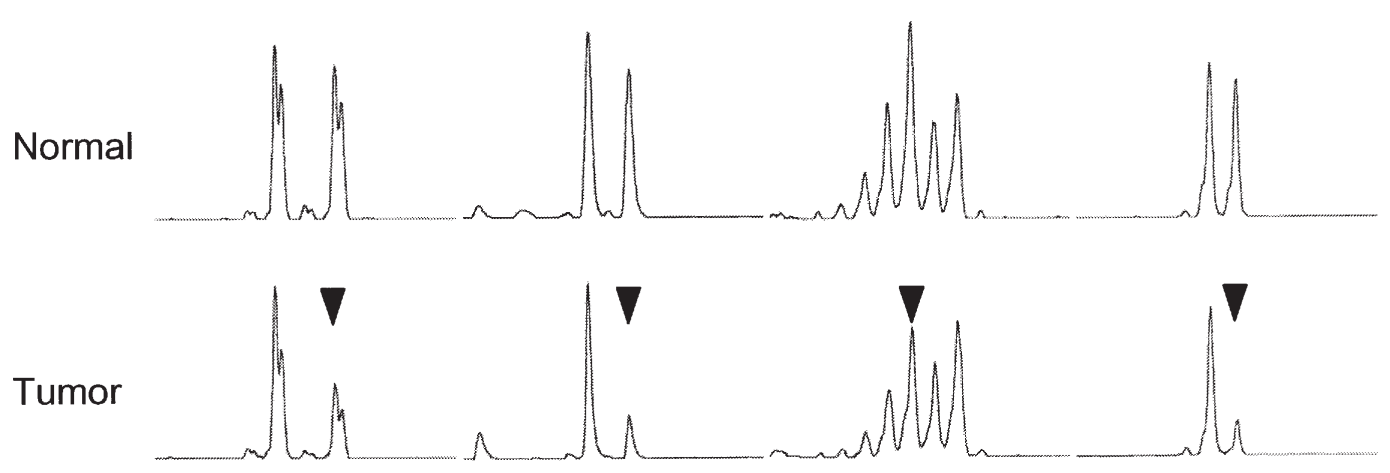

Figure 1. Representative AI cases of each microsatellite region, D11S1392, D13S317, TP53, and D18S538. A black triangle indicates the allele whose signal intensity is less than $70 \%$ compared to that of the corresponding allele in normal tissue.

A

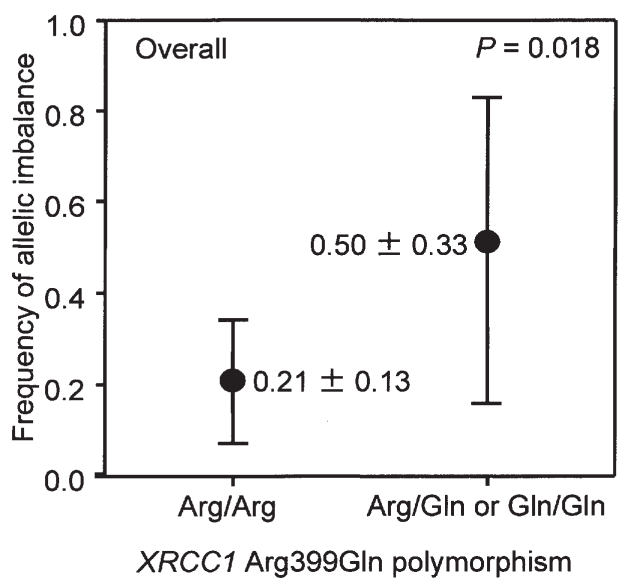

B

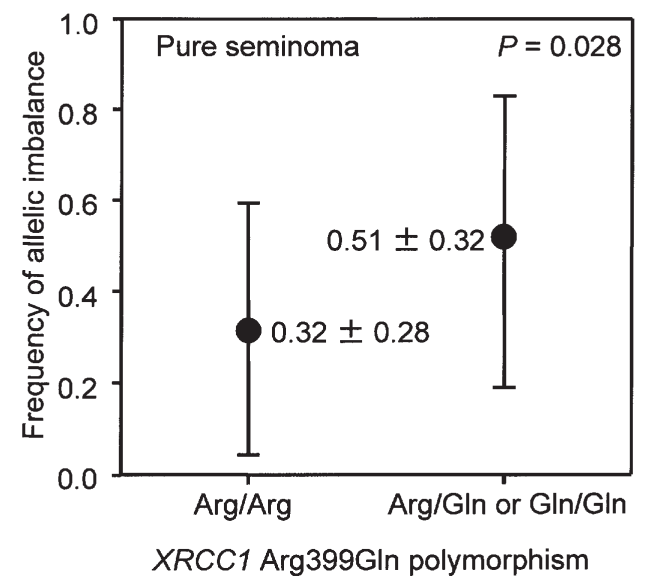

Figure 2. The frequency of $\mathrm{AI}$ in each group of XRCC1 genotypes in all cases of TGCT (A) and in cases of pure seminoma (B) (mean \pm SD). The frequency of AI in tumors with the Gln allele of the Arg399Gln polymorphism showed a significantly higher frequency than those with the Arg/Arg genotype in each group.

considered consistent risk factors of TGCT (35-37), whereas exposure to chemical materials, electromagnetic fields, or maternal or personal smoking, which possibly induce DNA damage, have demonstrated conflicting results (38-43). Ochratoxin A, a natural food contaminant, has been reported to have a possible association with TGCT development (10). Animal experiments demonstrated that the consumption of ochratoxin A or its in utero transfer induces addicts in testicular DNA, which may cause further DNA damage (44). Among genetic factors, polymorphisms involved in the hormonal environment are most likely related to TGCT, but DNA repair gene polymorphisms may also affect the development of TGCT through the functional differences of those genes against the exposure to risk materials.

Several studies have assessed the association of genetic polymorphisms with the risk of TGCT. However, only a few polymorphisms, including androgen receptor $C A G$ repeats, glutathione S-transferase P1 Ile 105Val, and bcl10 G13T and $C 24 G$ polymorphisms, are reported to influence the susceptibility, phenotype, or progression of the tumor $(15,16,45)$. Recently, Laska et al reported that nucleotide and base excision repair genes, XPD, ASE-1, ERCC1, XRCC3, OGG1 and $X P C$, were not related to the risk of TGCT in the Danish population (14). Meanwhile, there are many studies investigating the association between XRCC1 polymorphisms and cancer risk; however, these studies show conflicting results in various cancers. For example, in breast cancer, Kim et al (28) reported that a significantly higher risk was associated with the Gln/Gln genotype of the Arg399Gln polymorphism, while other reports observed no association between the polymorphism and breast cancer risk. In cancers of the lung (27), head and neck (26), and non-melanoma skin (46), the Arg/Arg genotype was shown to be associated with cancer risk, but all other reports failed to prove the association in these cancers. Meanwhile, the Arg194Trp polymorphism showed a similar tendency among various cancer types. Although most studies did not find an association between the polymorphism and cancer susceptibility, the $\operatorname{Trp} / \operatorname{Trp}$ or Arg/Trp genotype tends toward a lower risk of each cancer. Hu et al (47) recently conducted a meta-analysis for XRCC1 polymorphisms and revealed that the Trp allele of the Arg194Trp polymorphism was associated with a significantly lower risk when all tumor types were included. However, there was no association between the Arg399Gln 
polymorphism and overall cancer risk. In the same study, they found an effect of the Arg399Gln polymorphism on cancer risk in some ethnicities, suggesting that racial or environmental factors influence the significance of the polymorphism in particular types of cancer. In this study, we demonstrated that the XRCC1 Arg399GIn polymorphism may be associated with susceptibility to TGCTs and, especially, to seminoma. Since the sample size of our study is small, a further study with a larger number of TGCT patients is needed to confirm the results.

The AI of tumor suppressor genes (TSGs) is believed to be the key step to carcinogenesis in various cancers and frequent chromosomal deletions have been identified on particular chromosomal regions in TGCT which possibly harbor important TSGs $(17,18,48)$. Rothe et al previously analyzed AI at 25 chromosomal loci in 76 TGCTs using the microdissection technique (18). Our results for AI analysis showed that each frequency of $\mathrm{AI}$ at the 4 loci was almost concordant with the previous result and the slightly higher frequencies observed in our data may be caused by differences in the detecting method or setting the threshold for determining AI. Of the four loci selected in this study, D11S1392, TP53, and D18S538 harbor wilms tumor 1 (WT1), tumor protein p53 (TP53), and deleted in colorectal carcinoma (DCC) respectively, and no definite TSG has been identified for D13S317 (13q31). Since the association between these TSGs and tumor characteristics or clinical significance is unknown, further studies are needed to elucidate the issue. In this study, tumors with at least one Gln allele of the XRCC1 Arg399Gln polymorphism had a significantly higher frequency of overall AI than those with the Arg/Arg genotype. A decreased activity of DNA repair function due to the polymorphism may induce frequent chromosomal aberrations. Further studies are required to delineate the biological role of the Arg399Gln polymorphism in relation to chromosomal stability and DNA repair.

The AI of nucleotide excision repair genes has also been reported in ovarian, colon, and lung cancers (49). However, the frequency of AI varied among cancer types and no association of AI with an impact on carcinogenesis or cancer progression has been clarified. In regard to XRCC1, $\mathrm{CGH}$ analysis in TGCTs showed no large deletion on $19 q 13$ where the gene is mapped (17). In this study, the genotype was completely identical between peripheral blood DNA and tumor tissue DNA, suggesting that at least no apparent deletions existed in the XRCC1 polymorphic loci.

In conclusion, these results suggest that the XRCC1 Arg399Gln polymorphism may affect the susceptibility and progression of TGCT through effects on chromosomal stability. Further characterization of the relationships between polymorphisms of DNA repair genes and chromosomal aberrations may allow a better understanding of how the polymorphisms affect cancer development and progression.

\section{References}

1. Jemal A, Murray T, Ward E, Samuels A, Tiwari RC, Ghafoor A, Feuer EJ and Thun MJ: Cancer statistics, 2005. CA Cancer J Clin 55: 10-30, 2005.

2. McKiernan JM, Goluboff ET, Liberson GL, Golden R and Fisch H: Rising risk of testicular cancer by birth cohort in the United States from 1973 to 1995 . J Urol 162: 361-363, 1999.
3. Nichols CR: Testicular cancer. Curr Probl Cancer 22: 187-274, 1998.

4. Ekbom A, Richiardi L, Akre O, Montgomery SM and Sparen P: Age at immigration and duration of stay in relation to risk for testicular cancer among Finnish immigrants in Sweden. J Natl Cancer Inst 95: 1238-1240, 2003.

5. Garner MJ, Turner MC, Ghadirian P and Krewski D: Epidemiology of testicular cancer: An overview. Int J Cancer 116 : 331-339, 2005.

6. Richiardi L, Akre O, Montgomery SM, Lambe M, Kvist U and Ekbom A: Fecundity and twinning rates as measures of fertility before diagnosis of germ-cell testicular cancer. J Natl Cancer Inst 96: 145-147, 2004.

7. Swerdlow AJ, Huttly SR and Smith PG: Prenatal and familial associations of testicular cancer. Br J Cancer 55: 571-577, 1987.

8. Henderson BE, Benton B, Jing J, Yu MC and Pike MC: Risk factors for cancer of the testis in young men. Int J Cancer 23: 598-602, 1979.

9. Akre O, Lipworth L, Tretli S, Linde A, Engstrand L, Adami HO, Melbye M, Andersen A and Ekbom A: Epstein-Barr virus and cytomegalovirus in relation to testicular-cancer risk: a nested case-control study. Int J Cancer 82: 1-5, 1999.

10. Schwartz GG: Hypothesis: does ochratoxin A cause testicular cancer? Cancer Causes Control 13: 91-100, 2002.

11. Forman D, Oliver RT, Brett AR, Marsh SG, Moses JH, Bodmer JG, Chilvers CE and Pike MC: Familial testicular cancer: A report of the UK family register, estimation of risk and an HLA class 1 sib-pair analysis. Br J Cancer 65: 255-262, 1992.

12. Rajpert-De Meyts E, Leffers H, Daugaard G, Andersen CB, Petersen PM, Hinrichsen J, Pedersen LG and Skakkebaek NE: Analysis of the polymorphic CAG repeat length in the androgen receptor gene in patients with testicular germ cell cancer. Int $\mathbf{J}$ Cancer 102: 201-204, 2002.

13. Aschim EL, Giwercman A, Stahl O, Eberhard J, Cwikiel M, Nordenskjold A, Haugen TB, Grotmol T and Giwercman YL: The RsaI polymorphism in the ER \{beta\} gene is associated with male infertility. J Clin Endocrinol Metab 90: 5343-5348, 2005.

14. Laska MJ, Nexo BA, Vistisen K, Poulsen HE, Loft S and Vogel U: Polymorphisms in RAI and in genes of nucleotide and base excision repair are not associated with risk of testicular cancer. Cancer Lett 225: 245-251, 2005.

15. Harries LW, Stubbins MJ, Forman D, Howard GC and Wolf CR: Identification of genetic polymorphisms at the glutathione Stransferase Pi locus and association with susceptibility to bladder, testicular and prostate cancer. Carcinogenesis 18: 641-644, 1997

16. Giwercman A, Lundin KB, Eberhard J, Stahl O, Cwikiel M, Cavallin-Stahl E and Giwercman YL: Linkage between androgen receptor gene CAG trinucleotide repeat length and testicular germ cell cancer histological type and clinical stage. Eur J Cancer 40: 2152-2158, 2004.

17. Ottesen AM, Kirchhoff M, De-Meyts ER, Maahr J, Gerdes T, Rose H, Lundsteen C, Petersen PM, Philip J and Skakkebaek NE: Detection of chromosomal aberrations in seminomatous germ cell tumours using comparative genomic hybridization. Genes Chromosomes Cancer 20: 412-418, 1997.

18. Rothe M, Albers P and Wernert N: Loss of heterozygosity, differentiation, and clonality in microdissected male germ cell tumours. J Pathol 188: 389-394, 1999.

19. Bouras M, Tabone E, Bertholon J, Sommer P, Bouvier R, Droz JP and Benahmed M: A novel SMAD4 gene mutation in seminoma germ cell tumors. Cancer Res 60: 922-928, 2000.

20. Kemmer K, Corless CL, Fletcher JA, McGreevey L, Haley A, Griffith D, Cummings OW, Wait C, Town A and Heinrich MC: KIT mutations are common in testicular seminomas. Am J Pathol 164: 305-313, 2004.

21. Edwards AA, Virsik-Peuckert P and Bryant P: Mechanisms of radiation-induced chromosome aberrations. Mutat Res 366: 117-128, 1996.

22. Lunn RM, Langlois RG, Hsieh LL, Thompson CL and Bell DA: XRCC1 polymorphisms: effects on aflatoxin B1-DNA adducts and glycophorin A variant frequency. Cancer Res 59: 2557-2561, 1999.

23. Hsieh LL, Chien HT, Chen IH, Liao CT, Wang HM, Jung SM, Wang PF, Chang JT, Chen MC and Cheng AJ: The XRCC1 399Gln polymorphism and the frequency of p53 mutations in Taiwanese oral squamous cell carcinomas. Cancer Epidemiol Biomarkers Prev 12: 439-443, 2003. 
24. Lei YC, Hwang SJ, Chang CC, Kuo HW, Luo JC, Chang MJ and Cheng TJ: Effects on sister chromatid exchange frequency of polymorphisms in DNA repair gene XRCC1 in smokers. Mutat Res 519: 93-101, 2002.

25. Wang Y, Spitz MR, Zhu Y, Dong Q, Shete S and Wu X: From genotype to phenotype: correlating XRCC1 polymorphisms with mutagen sensitivity. DNA Repair 2: 901-908, 2003.

26. Olshan AF, Watson MA, Weissler MC and Bell DA: XRCC1 polymorphisms and head and neck cancer. Cancer Lett 178: 181-186, 2002.

27. David-Beabes GL and London SJ: Genetic polymorphism of $\mathrm{XRCC} 1$ and lung cancer risk among African-Americans and Caucasians. Lung Cancer 34: 333-339, 2001.

28. Kim SU, Park SK, Yoo KY, Yoon KS, Choi JY, Seo JS, Park WY, Kim JH, Noh DY, Ahn SH, Choe KJ, Strickland PT, Hirvonen A and Kang D: XRCC1 genetic polymorphism and breast cancer risk. Pharmacogenetics 12: 335-338, 2002.

29. Taylor RM, Thistlethwaite A and Caldecott KW: Central role for the XRCC1 BRCT I domain in mammalian DNA single-strand break repair. Mol Cell Biol 22: 2556-2563, 2002.

30. Sturgis EM, Castillo EJ, Li L, Zheng R, Eicher SA, Clayman GL, Strom SS, Spitz MR and Wei Q: Polymorphisms of DNA repair gene XRCC1 in squamous cell carcinoma of the head and neck. Carcinogenesis 20: 2125-2129, 1999.

31. Zhou W, Liu G, Miller DP, Thurston SW, Xu LL, Wain JC, Lynch TJ, Su L and Christiani DC: Polymorphisms in the DNA repair genes XRCC1 and ERCC2, smoking, and lung cancer risk. Cancer Epidemiol Biomarkers Prev 12: 359-365, 2003.

32. Shu XO, Cai Q, Gao YT, Wen W, Jin F and Zheng W: A population-based case-control study of the Arg399Gln polymorphism in DNA repair gene XRCC1 and risk of breast cancer. Cancer Epidemiol Biomarkers Prev 12: 1462-1467, 2003.

33. Mostofi FK and Sobin LH: Histological typing of testis tumors. International Histological Classification of Tumors. Vol. 16. WHO, Geneva, 1997.

34. UICC: TNM Classification of Malignant tumors. 3rd edition. Springer-Verlag, Berlin, 1989

35. Boyle P and Zaridze DG: Risk factors for prostate and testicular cancer. Eur J Cancer 29A: 1048-1055, 1993.

36. Skakkebaek NE, Berthelsen JG and Muller J: Carcinoma-in situ of the undescended testis. Urol Clin North Am 9: 377-385, 1982.

37. Swerdlow AJ, De Stavola B, Maconochie N and Siskind V: A population-based study of cancer risk in twins: relationships to birth order and sexes of the twin pair. Int J Cancer 67: 472-478, 1996.
38. Moller H: Work in agriculture, childhood residence, nitrate exposure, and testicular cancer risk: a case-control study in Denmark. Cancer Epidemiol Biomarkers Prev 6: 141-144, 1997.

39. Habash RW, Brodsky LM, Leiss W, Krewski D and Repacholi M: Health risks of electromagnetic fields. Part I: evaluation and assessment of electric and magnetic fields. Crit Rev Biomed Eng 31: 141-195, 2003.

40. Verreault R, Weiss NS, Hollenbach KA, Strader CH and Daling JR: Use of electric blankets and risk of testicular cancer. Am J Epidemiol 131: 759-762, 1990.

41. Pettersson A, Kaijser M, Richiardi L, Askling J, Ekbom A and Akre O: Women smoking and testicular cancer: one epidemic causing another? Int J Cancer 109: 941-944, 2004.

42. Coupland CA, Forman D, Chilvers CE, Davey G, Pike MC and Oliver RT: Maternal risk factors for testicular cancer: a population-based case-control study (UK). Cancer Causes Control 15: 277-283, 2004

43. Haughey BP, Graham S, Brasure J, Zielezny M, Sufrin G and Burnett WS: The epidemiology of testicular cancer in upstate New York. Am J Epidemiol 130: 25-36, 1989.

44. Gharbi A, Trillon O, Betbeder AM, Counord J, Gauret MF, Pfohl-Leszkowicz A, Dirheimer G and Creppy EE: Some effects of ochratoxin A, a mycotoxin contaminating feeds and food, on rat testis. Toxicology 83: 9-18, 1993.

45. Inoue T, Ito T, Narita S, Horikawa Y, Tsuchiya N, Kakinuma $H$, Mishina M, Nakamura E, Kato T, Ogawa O and Habuchi T: Association of BCL10 germ line polymorphisms on chromosome $1 \mathrm{p}$ with advanced stage testicular germ cell tumor patients. Cancer Lett (In press).

46. Nelson HH, Kelsey KT, Mott LA and Karagas MR: The XRCC1 Arg399Gln polymorphism, sunburn, and non-melanoma skin cancer: evidence of gene-environment interaction. Cancer Res 62: 152-155, 2002.

47. Hu Z, Ma H, Chen F, Wei Q and Shen H: XRCC1 polymorphisms and cancer risk: a meta-analysis of 38 case-contro studies. Cancer Epidemiol Biomarkers Prev 14: 1810-1818, 2005.

48. Peng HQ, Bailey D, Bronson D, Goss PE and Hogg D: Loss of heterozygosity of tumor suppressor genes in testis cancer. Cancer Res 55: 2871-2875, 1995

49. Takebayashi Y, Nakayama K, Kanzaki A, Miyashita H, Ogura O, Mori S, Mutoh M, Miyazaki K, Fukumoto M and Pommier Y: Loss of heterozygosity of nucleotide excision repair factors in sporadic ovarian, colon and lung carcinomas: implication for their roles of carcinogenesis in human solid tumors. Cancer Lett 174: $115-125,2001$ 